\title{
THE EFFECT OF ENVIRONMENTAL LEADERSHIP AND ENVIRONMENTAL PERSONALITY ON STAFFS' PERCEPTION TOWARD GREENING INSTITUTIONS
}

\author{
An Ex Post Facto Study at Provincial Government Institution, \\ South Sulawesi \\ ANDI MUHAMMAD SUBHAN \\ The State Polytechnic of Ujung Pandang \\ andi.msubhan@poliupg.ac.id
}

\begin{abstract}
This research is about studying the effect of environmental leadership and environmental personality on staffs' perception toward greening institutions. There were around 6 research problems have been solved, including dependency between environmental leadership and environmental personality with staffs' perception toward greening institutions. Therefore, an ex-post facto method by using 2 $x 2$ factorial designs had been applied. Each cell consisted of 16 staffs from provincial government institutions, South Sulawesi which selected randomly. There were three instruments have been developed such as Environmental Leadership (EL), Environmental Personality (EP), and Greening Institutions (GI) which measured in a scaling form. Its reliable was respectively .991 (EL), .907(EP), and .929 (GI). Data have been analyzed by implementing two-way ANOVA and Chi-Square. Research results show that there is highly significant difference of staffss' perception toward greening institutions between stafss who perceived their superordinate to have transformational environmental leadership rather than transactional. There is highly difference of staffs' perception toward greening institutions between staffs who has good and bad environmental personality. There is no significant interaction effect found between environmental leadership and environmental personality on greening institutions. Finally, there is dependency between environmental leadership and environmental personality with greening institutions. Based on these findings, it could be interpreted that staffs' perception toward greening institutions might have been affected by environmental leadership independently without considering environmental personality. Therefore, if the greening institutions would be improved, environmental personality and environmental leadership could be taken in to consideration separately.
\end{abstract}

Keywords: Leadership, Personality and Greening Institutions. 


\section{I.PENDAHULUAN}

Perubahan iklim (climate change) sudah merupakan isu global yang menyebabkan berbagai resiko terhadap sistem lingkungan (natural system) dan manusia (social system). Menurut Robertson and Barling, 2013, organisasi atau intitusi turut serta berkontribusi yang signifikan dalam perubahan iklim dan hal ini akan diperparah oleh seiring dengan aktivitas manusia (Jing Zhang 2014).

Sebuah organisasi atau institusi dapat dievaluasi terhadap tujuan jangka panjang (the primary goals) maupun tujuan jangka pendek (the subsidiary goals), namun demikian, institusi/lembaga tersebut dapat juga dievaluasi tujuannya terhadap orang (actors) disekeliling intitusi/lembaga tersebut dan sebuah Institusi/lembaga berpotensi menyebabkan pengaruh sangat luas, baik positif atau negatif, baik langsung maupun secara tidak langsung (young and Levi, 1999, dikutip Mitchell, 2008).

Menurut (Barrow, 2006), Green berarti ramah lingkungan (environmental friendly), sedangkan Greening adalah peningkatan kualitas lingkungan (environmental improvement), yang salah satu karakteristiknya adalah pergeseran ke arah tujuan pembangunan manusia (a shift towards human development goals). Lebih lanjut, Georg and Fussel, 2000 mendefinisikan greening institusi atau organisasi (greening of organization) adalah sebagai proses yang memberikan dasar bagaimana lingkungan berperan dalam organisasi/institusi, dan melihat bagaimana peran seseorang dan sosial pada lingkungan berkembang dalam konteks perilaku (behavior).

Sebuah organisasi atau institusi yang peduli terhadap lingkungan disekitarnya adalah sangat tergantung sejauh mana para pemimpin (leaders) mempunyai komitment (commitment) dan kepemimpinan (leadership) dalam memposisikan diri sebagai pengelola tertinggi (top managers) dalam implementasi fungsi-fungsi manajemen (management functions), sehingga dapat meningkatkan kinerja lingkungan dalam institusi tersebut (Boiral et al 
2014). Kepemimpinan adalah elemen terpenting untuk sebuah gerakan perubahan dalam suatu institusi kearah yang lebih baik. Kepemimpinan adalah penting dalam mempengaruhi dan memotivasi karyawan serta memobilisasi sumber daya dalam pemenuhan visi dan misi organisasi atau institusi.

\section{TINJAUAN PUSTAKA}

Dalam model integrasi perilaku organisasi atau institusi, menurut Colquitt et al, 2011 pimpinan (leader) dan karyawan (employee) sebagai individu dapat dinilai dari prestasi individu (individual outcomes) yaitu kinerja pekerjaan (job performance) atau perilaku yang memberikan kontribusi baik atau buruk dan komitmen organisasi (organizational performance) yaitu kuat atau lemah keinginan individu dalam organisasi atau institusi tersebut. Ada beberapa faktor mempengaruhi prestasi individu (individual outcomes) dalam sebuah organisasi. Adalah faktor karakteristik individu (individual characteristics) yaitu kepribadian (personality) dan mekanisme group (group mechanisms), yang salah satunya adalah gaya dan perilaku kepemimpinan (leadership styles and behaviors).

Lebih lanjut, Boiral, et al, 2014, kepemimpinan lingkungan dan greening korporasi/institusi adalah kemampuan mempengaruhi seseorang dan memobilisasi kemampuan organisasi untuk menyadari tujuan jangka panjang yang berkelanjutan secara ekologi. Kepemimpinan lingkungan telah mendorong gerakan greening dalam organisasi dan pimpinan tertinggi berperan penting dalam keterlibatan greening dalam empat bidang yaitu (i) Penerapan lingkungan (environmental practices) dan tanggungjawab (responsibilities), misalkan penerapan kebijakan keberlanjutan, tindakan pengurangan polusi. (ii) Motivasi (motivations) meliputi legitimasi sosial dan respon pada pemangku kepentingan (stakeholders), (iii) Dampak ekonomi (economic impacts) meliputi kontrol pengurangan polusi, peningkatan imej 
perusahaan, dan motivasi karyawan, (iv) Nilai-nilai (values), meliputi menempatkan nilai-nilai kepemimpinan lingkungan dan strategis keberlanjutan.

Menurut (Hirsh 2010), baik atau buruk suatu lingkungan, perilaku manusia mempunyai pengaruh besar terhadap kondisi ekologi secara global, sehingga dibutuhkan solusi yang berkenaan dengan perilaku. Peduli/ramah lingkungan (environmental concern) dapat dilihat dengan indikator laten diantaranya adalah pentingnya menjaga lingkungan (Importance of Environmental Protection'). Beberapa contoh penerapannya dalam organisasi/institusi adalah penggunaan energi listrik dan air, pengurangan volume sampah dan proses daur ulang, penggunaan sistem transportasi massal, dan isu-isu lingkungan lain tidak hanya memberikan kontribusi positif bagi organisasi atau institusi (greening of institution) akan tetapi juga mempengaruhi laju perubahan iklim (climate change) dan mencegah kerusakan lingkungan (environmental damage), khususnya lingkungan tempat kerja. Kondisi ini dibutuhkan individu pemimpin yang mempunyai kepemimpinan lingkungan (environmental leadership style) dan kepribadian lingkungan (environmental personality) yang kuat.

Menurut Krajhanzl, 2010 faktor-faktor dimensi kepribadian mendukung seseorang untuk berperilaku lingkungan. faktor kepribadian yang mempengaruhi perilaku lingkungan yang mempengaruhi kualitas karakteristik, karakteristik motivasi (sikap dan nilai-nilai), kemampuan dan suasana hati mental seseorang individu untuk berperilaku terhadap lingkungan. Seseorang termotivasi untuk memelihara alam dan lingkungan dan mencari cara bagaimana berperilaku dengan bertanggung jawab ke arah lingkungan. Misalkan memisahkan sampah, mengurangi penggunaan energi dan penggunaan produk ramah lingkungan. 
Sebuah institusi/organisasi Pemerintah sesuai dengan UU No 23 Tahun 2014 Pasal 1 tentang Pemerintahan Daerah, berdasarkan tugas dan fungsi tanggungjawab, aparat satuan kerja perangkat daerah (SKPD) dalam struktur pemerintahan daerah bersentuhan langsung dengan masyarakat yang menjalankan fungsi-fungsi manajemen (management functions) yaitu perencanaan (planning), pengorganisasian (organization), memimpin (leading) dan pengawasan (controlling).

Peran para aparat pemerintah mutlak harus memiliki kepemimpinan lingkungan (environmental leadership styles) dan kepribadian (environmental personality) dalam menjalankan peran dan fungsi manajemen dalam kepedulian lingkungan (environmental concern), khususnya dalam mengurangi resiko terhadap sistem lingkungan (natural system) dan manusia (social system).

Beberapa penelitian yang telah dilakukan sebelumnya antara lain yang dilakukan oleh Robertson and Barling, 2013, "Greening organizations through leaders' influence on employees' pro-environmental behaviors", mengembangkan model persamaan struktur (SEM) uji model hubungan antara kepemimpinan transformasional dan perilaku pemimpin yang prolingkungan di tempat kerja pada karyawan yang berperilaku pro-linkungan, hasil temuan riset ini menunjukkan bahwa pemimpin lingkungan mengambarkan norma dan kepemimpinan dan perilaku pro-lingkungan memainkan peran penting dalam greening organisasi. Berikutnya adalah oleh Boiral et al, 2013, "Environmental Leadership and Consciousness Development: A Case Study Among Canadian SMEs". Riset ini mengeksplorasi bagaimana hubungan antara Kepemimpinan lingkungan (environmental leadership) dan greening perusahaan (corporation greening) dalam berbagai tahap perkembangan kesadaran manajer puncak dapat mempengaruhi, dalam hal praktek, kemampuan dan komitmen untuk kepemimpinan lingkungan di berbagai perusahan. Hasil temuan riset ini 
menunjukkan greening perusahaan sangat tergantung pada komitmen dan kepemimpinan dari manajer puncak untuk menerapkan kebijakan dan praktik yang dapat meningkatkan kinerja lingkungan. Penelitian berikutnya adalah yang dilakukan oleh Hirsh, 2012 yaitu kepribadian dan kepedulian lingkungan (Personality and environmental concern), yang menguji hubungan antara karaktristik kepribadian dan kepedulian lingkungan dalam komunitas warga Negara Jerman dewasa sebanyak 2690. Hasil temuan riset ini menujukkan bahwa keterlibatan lingkungan yang besar terkait dengan dimensi kepribadian agreeableness dan openness. Penelitian berikutnya adalah yang dilakukan oleh Milfont and Sibley, 2012, yaitu "The big five personality traits and environmental engagement: Associations at the individual and societal level'. Keterkaitan antara sifat spesifik kepribadian dan kepedulian lingkungan telah diamati di sejumlah studi, namun hanya sedikit yang meneliti hubungan antara sifat kepribadian utama (the Big Five personality traits) dan keterlibatan lingkungan (environmental engagement). Penelitian berikutnya adalah yang dilakukan oleh Mario Solino and Begona A. Farizo, (2014), dengan judul riset adalah "Personal Traits Underlying Environmental Preferences: A Discrete Choice Experiment'. Penelitian ini menganalisis pengaruh kepribadian 5 (lima) dimensi kepribadian (extraversion, agreeableness, conscientiousness, neuroticism dan keterbukaan) berkaitan dengan dengan preferensi untuk pengembangan program lingkungan untuk pengelolaan hutan di Spanyol. Hasil penelitian menunjukkan efek positif dari dimensi keterbukaan (openness) dan extraversion (extraversion) dan efek negatif dari keramahan (agreeableness). Penelitian berikutnya adalah yang dilakukan oleh Andersen (2006), dengan judul riset "Leadership, personality and effectiveness". Penelitian ini melihat efektifitas hubungan antara kepemimpinan dan kepribadian. Hasil penelitian ini menujukkan terdapat hubungan antara kepemimpinan dan kepribadian, namun demikian kepribadian dan kepemimpinan menunjukkan hubungan yang tidak signifikan. 
Walaupun beberapa teori mengatakan bahwa hubungan antara kepribadian dan kepemimpinan sangat kuat. Penelitian berikutnya adalah yang dilakukan oleh Lannelongue et al, (2014), dengan judul "Environmental Motivations: The Pathway to Complete Environmental Management", melihat pengaruh kebijakan lingkungan pemerintah dalam hubungan antara motivasi lingkungan dan manajemen lingkungan, dengan jumlah data lebih dari 50 karyawan yang tersebar 7 negara yang terkabung dalam OECD. Hasil penelitian ini mengungkapkan terdapat pengaruh antara motivasi lingkungan dan manajemen lingkungan melalui pengawasan (monitoring) dan tindakan (action).

\section{III.METODOLOGI PENELITIAN}

Teknik pengumpulan data yang digunakan dalam penelitian ini adalah dengan menggunakan pendekatan kuantitatif, metode survey dan teknik expost facto melalui pengembangan butir instrumen untuk setiap variabel. Teknik pengambilan data menggunakan 3 (tiga) instrumen variabel, yaitu greening institusi ( $\mathrm{Y}$ ), kepemimpinan lingkungan (A) dan kepribadian lingkungan (B). Setiap instrumen penelitian mengacu pada konseptual yang meliputi definisi konseptual, definisi operasional, kisi-kisi instrumen penelitian. Validitas butir instrumen dengan teknik korelasi Pearson Product Moment dan pengujian reabilitas instrumen dengan rumus korelasi Alpha Cronbach.

Dalam analisis data, maka sampel yang dianalisis adalah $27 \%$ rangking atas dan $27 \%$ rangking bawah dengan mengurutkan nilai yang didapat dari hasil perhitungan skor butir instrumen kepemimpinan lingkungan. Dari 216 responden didapatkan 58 responden kelompok atas yang dipersepsikan tranformasional dan 58 responden kelompok bawah yang dipersepsikan transaksional. Dari kelompok kepemimpinan lingkungan (transformasional) dan kepemimpinan lingkungan (transaksional) dirangking untuk mendapatkan $27 \%$ kelompok atas sebagai kepribadian lingkungan tinggi dan $27 \%$ 
kelompok bawah sebagai kepribadian lingkungan rendah, sehingga masingmasing terdapat 16 responden. Teknik analisis data meliputi: (i) statistik deskriptif, (ii) Persyaratan analisis, (iii) Uji hipotesis dengan two-way ANOVA dan uji Chi-Square.

\section{HASIL PENELITIAN DAN PEMBAHASAN}

Berdasarkan hasil analisis yang telah dilakukan diperoleh infomasi bahwa untuk kepemimpinan lingkungan, nilai F-hitung mencapai 102,950 dengan probabilitas signifikansi ( $p$-value) sebesar $<0,001$. Dengan demikian, untuk $\alpha=0,05$ diketahui bahwa nilai $\mathrm{p}$-value $<\alpha$ yaitu $0,000<0,05$ yang berakibat $\mathrm{H}_{0}$ ditolak. Dengan demikian dapat dikatakan bahwa terdapat perbedaan skor institusi ramah lingkungan terhadap pegawai yang menilai atasannya yang memiliki kepemimpinan lingkungan transformasional $\left(A_{1}\right)$ dan pengawai yang menilai atasannya kepemimpinan lingkungan transaksional $\left(A_{2}\right)$. Skor institusi ramah lingkungan $(\mathrm{Y})$ kelompok bawahan yang mengpersepsikan pimpinan yang memiliki kepemimpinan lingkungan transformasional $\left(A_{1}\right)$ sebesar 79,25 sementara skor institusi ramah lingkungan $(Y)$ kelompok bawahan yang menpersepsikan pimpinan yang memiliki kepemimpinan lingkungan transaksional $\left(A_{2}\right)$ sebesar 55,00.

Karena terdapat perbedaan, maka dapat juga dikatakan bahwa terdapat pengaruh kepemimpinan lingkungan terhadap institusi ramah lingkungan. selanjutnya dikarenakan skor institusi ramah lingkungan kelompok pegawai yang mempersepsikan pimpinan memiliki kepemimpinan lingkungan transformasional $\left(A_{1}\right)$ lebih tinggi jika dibandingkan dengan kelompok bawahan yang mempersepsikan pimpinan memiliki kepemimpinan transaksional $\left(A_{2}\right)$, maka dengan demikian dapat dikatakan bahwa terdapat pengaruh positif kepemimpinan lingkungan terhadap institusi ramah lingkungan. 
Berdasarkan hasil analisis yang telah dilakukan diperoleh infomasi bahwa untuk Kepribadian Lingkungan, nilai F-hitung mencapai 6,757 dengan probabilitas signifikansi ( $p$-value) sebesar 0,016. Dengan demikian, untuk $\alpha=0,05$ diketahui bahwa nilai $\mathrm{p}$-value $<\alpha$ yaitu $0,016<0,05$ yang berakibat $\mathrm{H}_{0}$ ditolak. Dengan demikian dapat dikatakan bahwa terdapat perbedaan skor institusi ramah lingkungan terhadapa kelompok pegawai yang mempersepsikan pimpinan memiliki Kepribadian Lingkungan Baik $\left(B_{1}\right)$ dan kelompok bawahan yang mempersepsikan pimpinan memiliki Kepribadian buruk $\left(B_{2}\right)$. Skor institusi ramah lingkungan kelompok bawahan yang menpersepsikan pimpinan memiliki Kepribadian Lingkungan baik $\left(B_{1}\right)$ sebesar 79,25 sementara skor institusi ramah lingkungan kelompok pegawai yang menpersepsikan pimpinan memiliki Kepribadian Buruk $\left(B_{2}\right)$ sebesar 55,00 .

Karena terdapat perbedaan, maka dapat juga dikatakan bahwa terdapat pengaruh Kepribadian Lingkungan terhadap institusi ramah lingkungan. selanjutnya dikarenakan skor institusi ramah lingkungan kelompok bawahan yang menpersepsikan pimpinan memiliki Kepribadian Lingkungan baik $\left(B_{1}\right)$ lebih tinggi jika dibandingkan dengan kelompok pegawai yang menpersepsikan pimpinan memiliki Kepribadian buruk $\left(B_{2}\right)$, maka dengan demikian dapat dikatakan bahwa terdapat pengaruh positif Kepribadian Lingkungan terhadap institusi ramah lingkungan.

Berdasarkan hasil analisis yang telah dilakukan diperoleh infomasi bahwa untuk kepemimpinan lingkungan dan kepribadian lingkungan, nilai $F_{\text {hitung }}$ mencapai 0,488 dengan probabilitas signifikansi ( $p$-value) sebesar 0,522. Dengan demikian, untuk $\alpha=0,05$ diketahui bahwa nilai $\mathrm{p}$-value $>\alpha$ yaitu $0,522>0,05$ yang berakibat $\mathrm{H}_{0}$ diterima. Dengan demikian dapat dikatakan bahwa tidak signifikan interaksi antara kepemimpinan lingkungan dan Kepribadian Lingkungan dalam kaitannya dengan terbentuknya institusi 
ramah lingkungan (Greening Institusi). Pengaruh interaksi antara kepemimpinan dan kepribadian lingkungan dalam kaitannya dengan terbentuknya institusi ramah lingkungan sebesar 0,008. Hal ini berarti pengaruh interaksi antara kepemimpinan dan Kepribadian Lingkungan dapat menjelaskan $8 \%$ variansi institusi ramah lingkungan (Greening Institusi).

Karena terjadi interaksi yang tidak signifikan, maka hipotesis 3 dan 4 tidak dapat dilakukan pengujian lebih lanjut. Pada uji Chi Square, Ho ditolak pada $\alpha=0,05$ yang berarti ada hubungan dependensi antara kepemimpinan lingkungan dan kepribadian lingkungan terhadap terbentuknya institusi ramah lingkungan. Dengan demikian dapat dikatakan bahwa terdapat ketergantungan kepemimpinan lingkungan dan kerpibadian lingkungan terhadap terbentuknya institusi ramah lingkungan.

Tabel 1. Pengujian Two-way ANOVA.

\begin{tabular}{|l|c|c|c|c|c|c|}
\hline \multirow{2}{*}{$\begin{array}{l}\text { Sumber } \\
\text { varians }\end{array}$} & \multirow{2}{*}{$(\mathbf{J K})$} & $\mathbf{d k}$ & \multirow{2}{*}{$\mathbf{( R J K}$} & \multirow{2}{*}{$\mathbf{F}_{\text {hitung }}$} & \multicolumn{2}{|c|}{$\mathbf{F}_{\text {tabel }}$} \\
\cline { 6 - 8 } & & & & & $\mathbf{( \alpha = 0 , 0 5 )}$ & $\mathbf{( \alpha = 0 , 0 1 )}$ \\
\hline Efek A & 8235,563 & 1 & 8235,563 & $102,950^{* *}$ & 4,001 & 7,077 \\
\hline Efek B & 540,563 & 1 & 540,563 & $6,757^{* *}$ & 4,001 & 7,077 \\
\hline Int A x B & 39,063 & 1 & 39,063 & $0,488^{\text {ns }}$ & 4,001 & 7,077 \\
\hline Dalam & 4799,750 & 60 & 79,996 & & & \\
\hline Total & 13614,938 & 63 & 216,110 & & & \\
\hline
\end{tabular}

${ }^{* \star} \rho<0,05$; ns:non significant

Keterangan

$\mathrm{dk}=$ derajat kebebasan

$\mathrm{JK}=$ jumlah kuadrat

RJK = rerata jumlah kuadrat

Efek $A=$ kepemimpinan lingkungan

Efek $B=$ kepribadian lingkungan

Int $=$ Interaksi $\mathrm{A} \times \mathrm{B}$ 
Tabel 2. Tabel Uji Chi Square (Uji- $\left.\chi^{2}\right)$.

\begin{tabular}{|c|c|c|c|c|c|c|c|}
\hline Sel ke- & FA & $\mathbf{F H}=\mathbf{n}$ & $\mathbf{J T K} / \mathbf{n}$ & $\mathbf{J T B} / \mathbf{n}$ & $\mathbf{( F A}-\mathbf{F H})$ & $\mathbf{( F A ~ - ~ F H ) ~}^{2}$ & $\frac{(\mathbf{F A}-\mathbf{F H})^{2}}{\mathbf{F H}}$ \\
\hline 1.1 & 16 & 29 & 0.5 & 0.500 & -13 & 169 & 5.828 \\
\hline 1.2 & 16 & 29 & 0.5 & 0.500 & -13 & 169 & 5.828 \\
\hline 2.1 & 16 & 29 & 0.5 & 0.500 & -13 & 169 & 5.828 \\
\hline 2.2 & 16 & 29 & 0.5 & 0.500 & -13 & 169 & 5.828 \\
\hline & & & & & & $\chi^{2}$ & 23.310 \\
\hline
\end{tabular}

\section{KESIMPULAN}

Hal ini dapat disimpulkan bahwa persepsi pegawai terhadap institusi ramah lingkungan dapat dipengaruhi melalui kepemimpinan lingkungan tanpa mempertimbangkan kepribadian lingkungan. Namun demikian, jika institusi ramah lingkungan ingin ditingkatkan, kepemimpinan lingkungan dan kepribadian lingkungan dapat diambil dalam pertimbangan masing-masing.

Penelitian ini memberikan implikasi bahwa kepemimpinan transaformasional (aktif dan efektif) pejabat satuan kerja perangkat daerah berperan dalam mengarahkan dan mempengaruhi pegawai yang akan berdampak baik melalui pengambilan keputusan dan pencapaian kinerja dan komitmen institusi ramah lingkungan. Sehingga pemenuhan regulasi yang mendorong pengurang resiko lingkunga akan berdampak peningkatan perbaikan kualitas lingkungan dalam mendukung program SulSel go green dan pengembangan kawasan terpadu Mamminasata.

Kepribadian lingkungan melalui dimensi Keramahan (agreeableness), terbuka (openness) dan ketelitian (conscientiousness) akan berdampak perubahan lingkungan (environmental changes) dan dalam diri staf (within individual) terhadap kepedulian lingkungan (environmental concern). Ini berarti semakin baik dimensi kepribadian lingkungan pejabat satuan kerja perangkat daerah dengan selalu menyuarakan perbaikan kualitas lingkungan kerja, 
menjalankan peraturan yang berkaitan dengan perbaikan lingkungan dan penghematan penggunaan peralatan ATK akan akan mengakibatkan peningkatan perbaikan kualitas lingkungan dalam mendukung dalam mendukung program SulSel go green dan pengembangan kawasan terpadu Mamminasata.

\section{REFERENSI}

Andersen, Jon Aarum, "Leadership, Personality and Effectivitas", Journal of Socio Economics, Vol. 35, Elsevier 2006, hh. 1078-1091.

Boiral et al. "Environmental Leadership and Consciousness Development:." Journal Busissness Ethics, 2014: 363-383.

Barrow, Chris J., Environmental Management for Sustainable Development. Second Edition (New York: Routledge: 2006.

Colquit et al. Organizational Behavior. New York: McGraw-Hill, 2011.

Gallagher, Deborah rigling. Environmental Leadership, Los Angeles: Sage, 2012.

Georg, Susse and Fussel, Lanni, "Making sense of Greening and organizational change", Journal of Business Strategy and the Environment, Vol.9, 2000, hh. 175-185.

Kalshoven, Karianne; Den Hartog, Deanne N., and De Hoogh, Annebel H. B., "Ethical Leader Behavior and Big Five Factors of Personality", Journal of Business Ethics,Vol. 100, Springer 2011, hh. 349-366. 
Krajhanzl, Jan. "Environmental and proenvironmetal behavior", Health Education: International Experiences, http// www.ped.muni.cz/z21/knihy/2011/36/36/.../krajhanzl.pdf (diakses 4 Juni 2016)

Lannelongue, Gustavo; Benito, Oscar Gonzalez and Benito, Javier Gonzalez, Environmental Motivations: The Pathway to Complete Environmental Management, Journal of Business Ethic, Vol. 124, Springer.

Leverett, Merium, Going Green with Values and Ethics in the 21st Century, Journal of Practical Consulting, Vol. 5,

Mitchell, Ronald B. "In Institution and Environmental Change: Principal Findings, Applications, and Research Frontiers." New York: MIT Press, 2008.

Milfont and Sibley. "The big five personality traits and environmental engagement: Associations at the." Journal of Environmental Psychology, 2012: 187-195.

Putrawan, I Made, Pengujian Hipotesis Dalam Penelitian-Penelitian Sosial, Jakarta: Rineka Cipta, 1990.

Robertson, Jenifer L and Barling, Julian. "Greening organizations through leaders' influence." Journal of Organizational Behavior, 2013: 176194. 
IJEEM: Indonesian Journal of Environmental Education and Management, Volume 1 Nomor 1 Januari 2016

Solino and Farizo. "Personal Traits Underlying Environmental Preferences:

A." PLOS ONE , 2014.

Ugur Yozgat, Higun Karatas. "Going Green of Mission and Vision Statement:

Ethical, Social, and Environmental Concerns across

Organizations." Procedia Social and Behavioral Sciences, Elsevier

Ltd, 2011: 1359-1366. 